\title{
Towards Independence of Soybean Farmers in Indonesia
}

\author{
Ivan Sayid Nurahman* Tiktiek Kurniawati \\ Faculty of Agribusiness, Galuh University, R. E. Martadinata Street No. 150 Ciamis, \\ 46274 West Java, Indonesia
}

\begin{abstract}
The research identified a form of independence of soybean farmers in farming development by taking cases in soybean development centers, namely Jatiwaras District, Tasikmalaya Regency, West Java Province, Indonesia. This study used a qualitative descriptive method by taking a sample of 127 soybean farmers using simple random sampling method. The forms of farmer independence were analyzed descriptively with a data presentation of the proportion of respondents' answers. The results showed that the independence of soybean farmers was mostly built from social independence $(65.35 \%)$ which was then followed by emotional independence $(51.97 \%)$, intellectual independence (32.28\%) and economic independence $(21.26 \%)$.
\end{abstract}

Keywords: Independence, Soybean, Farmers

DOI: $10.7176 / \mathrm{JEP} / 11-24-12$

Publication date: December $31^{\text {st }} 2020$

\section{Introduction}

Soybean is a strategic food commodity after rice and maize whose demand is getting higher along with population growth in Indonesia. The increase in consumption, which continues to increase until now, has not been able to be matched by the increase in domestic production (Figure 1). The main solution to overcome these problems is through imports which on the other hand often cause price and supply fluctuations in the market. Various efforts to increase domestic production have been carried out, but have not shown the expected results. This is in line with what Nurahman et al (2019) stated that the demand for soybean commodities is estimated to continue to increase along with the increasing population. Meanwhile, the increasing demand for soybeans was not followed by sufficient domestic production. The imbalance between supply and demand forces the government to import soybeans.

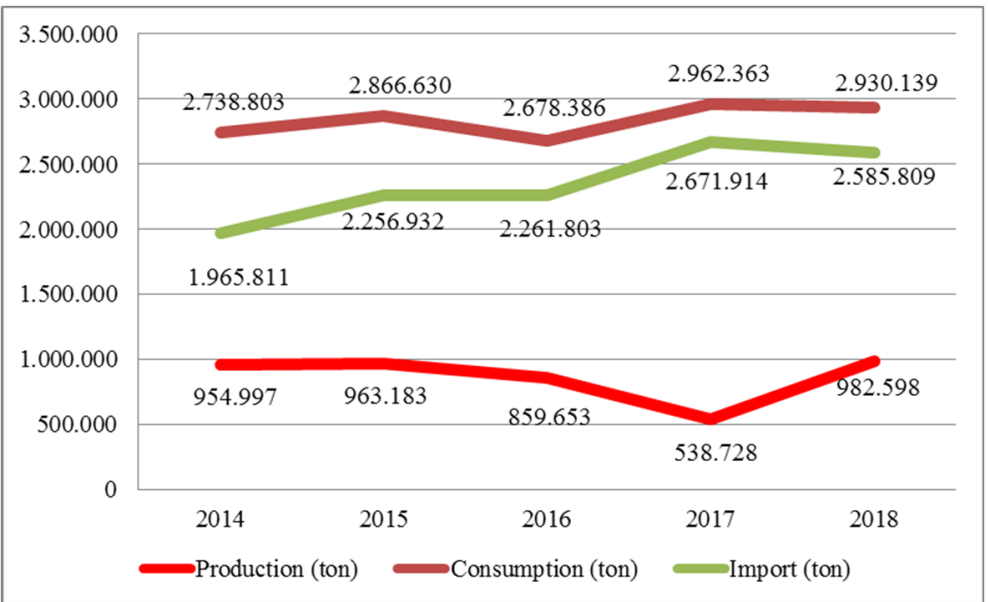

Source: Center for Agricultural Data and Information Systems, 2019

Figure 1. Development of Soybean Production, Consumption and Imports in Indonesia, 2014-2018

There is concern that this condition will increase dependence on imported soybeans. As stated by Hasan et al (2015) and Supadi (2009), the gap between the relatively larger needs compared to the amount of soybean production in Indonesia for decades has triggered dependence on imported soybeans. The high dependence on imports occurs because farmers are faced with various risks and uncertainties to run soybean farming. One of them is the high risk of pests and diseases and the price of domestic soybeans which tends to be expensive, which makes imported soybeans more attractive to the public and the price is cheap compared to domestic soybeans.

Soybean imports in large quantities is a very sad thing, considering that most of the Indonesian population works in the agricultural sector. Rasahan (1999) states that for developing countries, dependence on food imports can threaten social, economic and political stability. Efforts are needed to overcome these problems, one of which is the empowerment of farmers through various assistance programs (incentives) and farmer assistance to be able to continue to carry out soybean farming independently and sustainably. Wulanjari and Setiani (2018) state that empowerment must be able to change behavior and touch all aspects that are needed by the community (farmers). It is hoped that through the empowerment process, farmers will be more motivated to continue to carry out soybean 
farming independently and sustainably.

Tasikmalaya Regency is a center for developing potential soybean production in West Java. This potential is very supportive of efforts to achieve self-sufficiency in soybeans, where in the southern part of Tasikmalaya Regency, there are land resources that are still not optimized, including many unproductive lands, one of which is a former rubber plantation located in Jatiwaras District. As described above, this study aims to identify the form of independence of soybean farmers in developing soybean farming in Jatiwaras District, Tasikmalaya Regency.

\section{Literature Review}

\subsection{Independence}

The lives of farmers today are increasingly faced with complex problems, especially during the Covid-19 pandemic like now. This condition requires each individual farmer to find solutions and be able to solve any problems faced without having to depend on others and dare to determine the right attitude quickly. Hariyadi and Muslikah (2013) state that one of the important aspects needed to face this difficult situation is to be independent in attitude and action. Because basically every human being is born in a helpless condition, then every individual will need other people in his environment. As time goes by, every human being will slowly develop and learn independently to meet his every need.

Independence according to Havinghurst (1972) is the action of a person to try to solve the problem at hand without expecting help from others. That person will be responsible for decisions that have been made based on considerations of himself. Sukadji (1986) defines independence as the ability to regulate oneself according to the rights and obligations they have, be responsible for their own decisions, actions, and feelings. Whether related to physical actions or psychological feelings. It is also able to get rid of behavior that avoids reality, so that someone who is trained to stand on his own can solve his own problems. Independence is referred to as a person's freedom to determine their own future. This means that the person makes plans for his life based on his own desires.

Widayati (2009) states that there are several aspects of independence including:

1. Responsibility, namely the ability to assume responsibility, the ability to complete a task, be able to account for the results of its work, the ability to explain new roles, have principles about what is right and wrong in thinking and acting.

2. Autonomy, shown by doing one's own task, which is a condition indicated by actions that are done on their own and not by others and are not dependent on others and have self-confidence and the ability to take care of themselves.

3. Initiative, shown by the ability to think and act creatively.

4. Self-control, strong self-control is shown by controlling actions and emotions to be able to overcome problems and the ability to see other people's points of view.

In addition, Havinghurst (1972) argues that independence consists of several aspects, namely:

1. Emotion, this aspect is shown by the ability to control emotions and does not depend on the emotional needs of others.

2. Economy, this aspect is shown by the ability to regulate the economy and does not depend on the economic needs of others.

3. Intellectual, this aspect is shown by the ability to overcome various problems faced and the ability to develop creativity and innovation.

4. Social, this aspect is shown by the ability to interact with other people and not wait for actions from others. Independence in a person continues to increase according to developmental age. According to Desmita (2011), the characteristics of independence based on their levels are as follows: (1) impulsive and self-protective, (2) conformistic, (3) self-aware, (4) conscientious, and (5) individuality.

\subsection{Soybean Farmer}

Farmers as an element of farming play an important role in maintaining plants or livestock so that they can grow well, they act as farm managers. Farmers as farm managers mean that they have to make various decisions in utilizing land that is owned or leased from other farmers for the welfare of their family life (Rodjak, 2006). The farmer referred to in this research is a person who grows soybeans with the aim of obtaining a life from this activity. Judging from the relationship with cultivated land, farmers can be divided into:

a. Farmers who own tenants are farmers who have their own business land and the land is cultivated or cultivated independently and the status of the land is called owned land.

b. Tenant farmers are farmers who cultivate other people's land or other farmers with a lease status.

c. A farmer (tenant) is a farmer who works on land owned by other farmers using a production sharing system.

d. Pawnshop farmers are farmers who work on other people's land with a pawn system.

e. A farm worker is a farmer who owns the land or does not own his own farm, who usually works on the farm land of the owner or lessee and receives a wage, in the form of money or goods from farming, such as rice or other food 
Today there may be no more fully subsistence or fully commercial farmers, now most of the farmer groups are in the semi-commercial stage (Johnson, 1981). According to Ilham (2007) the empirical conditions regarding farmers and the agricultural sector will be better understood by farmers themselves than outsiders. Therefore, to analyze the farmer's profile and the problem, it must be seen from the perspective of the farmers themselves. The farmer and his family, his business, his labor, his consumption, his assets and debts, his plans, hopes and concerns which give direction and characteristics to the current agricultural system. This effort can be done by collecting data and information from farmers and their environment. The type of commodity cultivated by farmers can affect the profile of the farmer which includes demographic, asset control, employment, technology and institutional aspects.

Based on the results of the 2018 Central Bureau of Statistics (BPS) census, it shows that currently the motivation of farmers to plant soybeans is very low because the structure of soybean production costs is much greater than the value of production produced per year from each hectare of soybean land. This means that efforts are needed to make farmers excited again to develop soybeans, including by providing incentives and assistance. Farmers' assistance in carrying out soybean farming is intended to facilitate farmers in carrying out their farming so that it is hoped that in the future farmers will be able to run soybean farming independently.

\section{Methods}

This research was conducted using an explanatory survey method, namely explaining the symptoms of farmer behavior and the relationship between research variables (Indraningsih, 2013). Jatiwaras Subdistrict was chosen deliberately (purposive sampling) as a sample area with the consideration that it is a potential soybean development area in West Java. The research sample was taken using simple random sampling technique to all soybean farmers in Jatiwaras District who were included in the study population. The number of research samples was 127 soybean farmers, which were obtained from the calculation of the research sample using the Solvin formula as follows (Mun'im, 2012).

Where:

$$
n=\frac{N}{1 . N e^{2}}
$$

$\mathrm{n}=$ Sample size

$\mathrm{N}=$ Population

$\mathrm{e}=$ margin of error (in this study set at 0.05 with a $95 \%$ confidence level)

The data collected in this study consisted of secondary data and primary data. Secondary data were obtained from tracing various research results, literature studies, reports and documents from various agencies related to research. Primary data obtained from direct observation of the object of research and surveys using a questionnaire. The answer format in the questionnaire uses a Likert scale with four alternative answers.

The form of independence of soybean farmers is measured using indicators of social, economic, emotional and intellectual independence. The total score of each respondent was converted into a percentage of the respondents' answers which were then analyzed descriptively using the following formula (Sumardjo, 1999):

$$
\text { Indicator index }=\frac{\text { Total indicator score achieved }- \text { minimum number of indicator scores }}{\text { Maximum number of indicator scores }- \text { minimum number of indicator scores }} \times 100
$$

Descriptive analysis is an analysis that is classified as an attempt to determine, describe or identify what exists, in the form of synthesis and not analyzing (Ethridge, 2004).

\section{Result and Discussion \\ 4.1 Social Independence}

According to Dowling (1981), the essence of independence in (social) society is the potential to benefit from special treatment that is applied in various institutionalized patterns in local communities. The tragedy that paralyzed the lives of many parties could bring back the passion of community solidarity. Society also acts outside the ratio of economic thinking, but relies more on conscience. This situation has opened the widest possible place for the whole community in actualizing the independence of each individual. In other words, in today's society, the independence of the community makes the circulation of economic resources run dynamically at a level of social life. So it is not an exaggeration if the community relies on the strength of the community's potential which is managed independently as the opening key to solving problems as well as an effort to improve community welfare.

Social independence in this study is defined as the ability of farmers to interact with other farmers and not wait for actions from others. The results show that $65.35 \%$ (Figure 2) farmers have social independence, meaning that soybean farmers are able to independently interact with other farmers without instructions or instructions from other people in terms of developing their soybean farming. Often they open themselves to the outside environment to simply share knowledge and experiences of soybean farming. This is in line with the results of research by Marliati et al. (2010) which states that the social system has a direct effect on the independence of food crop 
farmers.

\subsection{Emotional Independence}

According to Monks (2001), essentially emotional independence cannot be separated from social independence, which means a person's ability to not depend on others emotionally and socially and to be responsible for what he does. Emotional and social independence in an individual context certainly has a broader aspect than just physical aspects. Emotional and social independence includes: behavior capable of taking initiative, being able to overcome obstacles / problems, having self-confidence and being able to do something on your own without the help of others. This opinion is also reinforced by Santrock (2005) which states that emotional and social independence is the desire to do everything for oneself.

In short, it can be concluded that emotional independence is the ability to control emotions and is independent of the emotional needs of others. The results show that $51.97 \%$ (Figure 2) farmers have emotional independence, meaning that soybean farmers are able to control their emotions (take responsibility for what they do) in carrying out soybean farming. As stated by Djuliansah et al (2020), soybean farmers sometimes do what they want (tacit knowledge) as an implementation of previous farming experiences, although it is different from what the government recommends.

\subsection{Intellectual Independence}

Intellectual independence according to Dwirayani et al. (2015) is defined as the ability that is manifested / displayed by farmers to criticize various issues related to agribusiness (provision and use of production facilities, production processes, marketing and processing of better agricultural products) intelligently and logically without being overshadowed by feelings. fear or pressure from others. Intellectual independence also means the formation of a base of autonomous knowledge by peasants that enables them to cope with more subtle forms of domination that arise beyond the control of that knowledge. Furthermore, Marliati et al (2010) argue that the intellectual independence of farmers is the ability to use land, time and opportunities to increase productivity and income, the ability to make rational decisions, the ability to solve problems, and so on.

Intellectual independence in this study is defined as the ability of farmers to overcome various problems faced and the ability to develop creative and innovative abilities in carrying out soybean farming. The results show that $32.28 \%$ (Figure 2) farmers have intellectual independence, meaning that soybean farmers are able to independently solve various problems faced and have the ability to develop creative and innovative abilities in carrying out soybean farming, although sometimes they have to be accompanied by instructors and facilitators. agriculture). This is in line with the results of research by Maryam (2016) regarding the development of food commodities, where farmers have high intellectual independence when accompanied by a training program.

\subsection{Economic Independence}

According to Mukeri (2012), the concept of independence is a very important factor in development. This concept does not only cover the notion of self-sufficiency in the economic field, but also includes the human factor personally, which contains elements of self-discovery based on self-confidence (sefconfidence). Independence is an attitude that prioritizes one's own ability to overcome various problems in order to achieve one goal, without closing oneself to the possibilities of mutually beneficial cooperation.

Economic independence in this study is defined as the ability of farmers to regulate the economy (farming costs) so as not to depend on other people and government assistance programs. The results show that $21.26 \%$ (Figure 2) farmers have economic independence, meaning that soybean farmers have not been able to independently carry out soybean farming by utilizing the capital they have to be optimized, they still depend on government assistance programs related to soybean development. So that most farmers run soybean farming with minimal input and simple technology. 


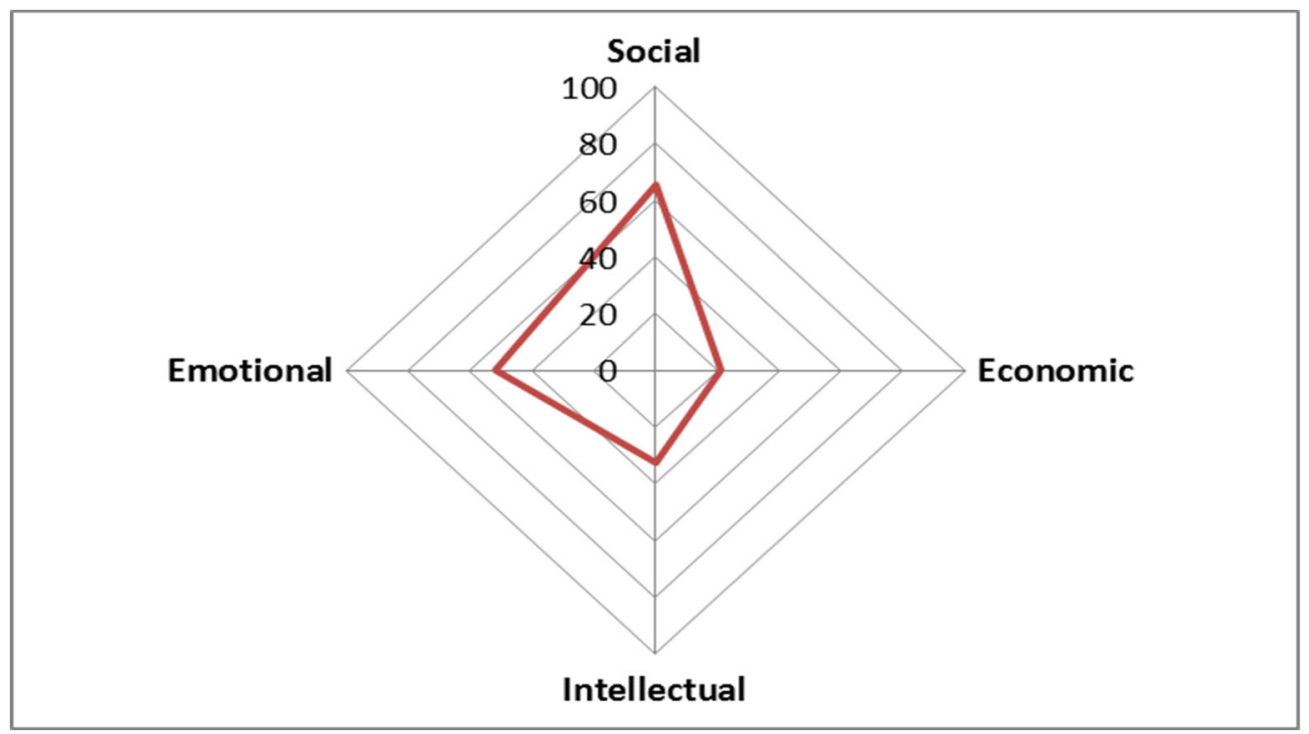

Source: Primary data (processed), 2020

Figure 2. Percentage of Independent Aspects of Soybean Farmers

\section{Conclusion}

The independence of soybean farmers as a whole can be achieved through various forms of independence. The results showed that soybean farmers have a very large social independence (dominant) compared to other independence (emotional, intellectual, and economic). The high level of social independence of soybean farmers is reflected in the interaction and participation of soybean farmers in farmer groups. Good interaction among farmers makes farmer knowledge more and more rich in insight. Emotional, intellectual, and economic independence of soybean farmers needs to be built with appropriate and participatory efforts. So it is expected that these forms of farmer independence will be integrated with the objectives of agricultural development.

\section{References}

Colette Dowling. 1981. Tantangan wanita modern: Ketakutan Wanita akan Kemandirian. Erlangga. Jakarta.

Djuliansah, Dedi, Trisna Insan Noor, Yosini Deliana, Meddy Rachmadi. 2020. Faktor-Faktor yang Berpengaruh Terhadap Tingkat Kemandirian Petani Kedelai di Kecamatan Pancatengah Kabupaten Tasikmalaya. Jurnal Mimbar Agribisnis. Vol 6, No 2 (2020).

Dwirayani, Dina, Hepi Hapsari, Tuhpawana P.Sendjaja. 2015. Analisis Faktor-Faktor yang Berpengaruh terhadap Tingkat Kemandirian Petani Mangga Gedong Gincu (Studi Kasus Desa Pasirmuncang dan Desa Cijurey, Kecamatan Panyingkiran Kabupaten Majalengka). Jurnal Ilmu Pertanian dan Peternakan Volume 3 Nomor 1 Juli 2015.

Hariyadi, Sigit dan Muslikah. 2013. Perkembangan Individu. Universitas Negeri Semarang Press.

Havinghurst, Robert J. 1972. Perkembangan Manusia dan Pendidikan. Allyn and Bacon. Bandung.

Marliati, Sumardjo, Pang S. Asngari, Prabowo Tjitropranoto, dan Asep Saefuddin. 2010. Faktor-Faktor yang Berpengaruh terhadap Kemandirian Petani Tanaman Pangan Beragribisnis di Kabupaten Kampar, Provinsi Riau. Jurnal Forum Pascasarjana Vol. 33 No. 3 Juli 2010:221-228

Maryam, Shoufi .2016. Pengaruh Pelatihan Budidaya Padi, Jagung Dan Kedelai Terhadap Peningkatan Kemandirian Petani Anggota P4s Kabupaten Subang : Studi Deskriptif Pada Pusat Pelatihan Pertanian Pedesaan dan Swadaya Binaan BBPP Lembang Wilayah Kab. Subang. Tesis, Universitas Pendidikan Indonesia.

Mukeri, M. 2012. Kemandirian Ekonomi Solusi untuk Kemajuan Bangsa. Jurnal Majalah Ilmiah Universitas Pandanaran Vol 10, No 24 (2012).

Nurahman, Ivan Sayid. Setiawan, Iwan. Noor, Trisna, Insan. 2019. Motivasi Petani dan Efektivitas Kelompok Tani dalam Pengembangan Kedelai pada Program Upsus Pajale di Kecamatan Jatiwaras Kabupaten Tasikmalaya. Prosiding Seminar Nasional Hasil Penelitian Agribisnis III. Universitas Galuh Ciamis.

Rasahan, CA. 1999. Kebijakan Pembangunan Pertanian Untuk Mencapai Ketahanan Pangan Berkelanjutan. Dalam: Tonggak Kemajuan Teknologi Produksi Tanaman Pangan. Konsep dan Strategi Peningkatan Produksi Pangan. Puslitbang Tanaman Pangan. Badan Litbang Pertanian. Hal 1-11.

Supadi. 2009. Dampak Impor Kedelai Berkelanjutan Terhadap Ketahanan Pangan. Jurnal Analisis Kebijakan Pertanian. Volume 7 No. 1, Maret $2009: 87-102$. 